\title{
International Trade Arising from Wage Differences
}

\section{Sikander Rahim*}

\begin{abstract}
This paper analyzes how trade can develop between low and high wage countries when there is free trade and when there is protection. In particular, the paper focuses on Pakistani industrial development from the 1950's and how standard international trade theory relies on specific assumptions about the nature of capital, which may not hold. This, in turn, has specific implications for industrial policy in low wage countries.
\end{abstract}

JEL Classification: F19, J00, J39.

Keywords: International trade, investment, comparative advantage

\section{Preliminaries}

The following is an attempt to describe how trade can develop between low- and high-wage countries when it is free and how it is affected by protection. Differences in wage rates between poor and rich countries and their persistence are facts that can be expected to persist for a long time; countries that had high-wages 50 years ago are still high-wage countries and only a few that had low-wages then have high-wages now. Firms will take wage rates into account when they make decisions to invest. The procedure adopted here is to start with the differences in wage rates, classifying countries as low-wage or high-wage, and to see where it leads.

For the sake of brevity, the term "goods" means nonfactor services as well. All goods are either tradable with negligible transport costs, or nontradable. Manufactured goods are made with the use of capital equipment, itself consisting of manufactured goods (buildings, machinery, plant, rolling stock, tools, etc.) that last for several periods, combined with labor. So the cost of production of a good, in addition to the cost of intermediate inputs such as raw materials, consists of the wage of the workers and the gross profit on the investment in capital equipment. Firms want the net profit rates, i.e., the ratio of gross profit less depreciation to the cost of investment, to be as high as possible. It is assumed that the techniques of production for manufactures work in exactly the same way in

\footnotetext{
${ }^{*}$ Former World Bank official.
} 
all countries, provided the workers have the requisite knowledge, which is the same for each country. Primary products, agricultural and mineral, are produced with labor and, perhaps, capital equipment, though they may require natural resources that not all countries have. Markets are competitive and efficient, so that the price of a tradable good is the same in all countries when calculated at the going exchange rate (the Law of One Price). Consequently, leaving aside possible complications that might be caused by differences in the prices of nontradable goods, differences in nominal wages are differences in real wages.

\section{Simple Goods}

To begin, it is assumed that no special knowledge or training is needed to produce goods; a worker in one country is the same as a worker in any other country. When a firm in a low-wage country produces a tradable good that is also produced by firms in high-wage countries, it receives the same price. But, having a lower nominal wage, its rate of profit is higher. Such firms choose to produce the good that yields the highest rate of profit and, by investing to increase its output, they displace production of that good by firms in the high-wage countries. The latter firms can try to compete by lowering their prices, but at the point at which they no longer cover their labor costs the former firms make a profit. If the high-wage country firms have foresight and know that they will not be protected, they give up the production of that good as the output of the low-wage countries increases, and, even if they do not wish to give it up, sooner or later they must. As they do so, they turn to producing other goods, for instance the capital goods used by the low-wage country firms.

Once the production of a good has been transferred completely to the low-wage countries, competition brings the price down to the point at which firms in these countries find it more profitable to produce another good that is made in the high-wage countries and the process is repeated. Production in low-wage countries grows and unemployment falls at rates determined by the pace of investment, which may be increased by foreign direct investment (FDI) of high-wage country firms induced by the higher rates of profit than available in their own countries. It is conceivable that the flow of FDI becomes so great that the capital stock of the high-wage countries is not replaced and employment falls, but it will be assumed that the authorities in these countries have means of preventing that.

Eventually, the low-wage countries as a whole reach full employment. What happens after that need not be discussed here. It is assumed here that, in any individual low-wage country, the wage rises with 
full employment. In reality, real wages can rise when there is unemployment and need not rise even with full employment, but there is a presumption that they are more likely to rise the less the unemployment, other things being equal. If need be, the assumption can be modified.

\section{Exporting Against Trade Barriers}

What needs to be explained is that this straightforward process has not occurred. At least part of the explanation can be seen from the example of Pakistan's investment in cotton textile manufacture. During the early phase of Pakistan's industrialization, the 1950s and 1960s, it was standard advice to lowwage countries that they should not invest in capital-intensive industries, but in industries like cotton and jute manufacturing, which were supposed to be labor-intensive. Pakistan's main industrial investments were in cotton and jute manufacturing, first to substitute for imports and then to export. Its income from these activities was the value of the imports it saved or the value of the exports, less the cotton or jute it would have exported but used in the manufacture and the foreign exchange cost of other inputs, such as dyes and energy. That is to say, value added at world prices.

Pakistan would have been an early example for the process described here had the high-wage countries not protected their own cotton and jute manufacturing. Protection against imports was normal in the early years after World War II; the high-wage countries protected their manufacturing industries. They began to lower the barriers to trade in the mid-1950s, but kept their protection against the main manufactured exports of the low-wage countries, cotton products being the most important. Even the preferences that the UK gave to its former colonies were replaced by restrictions on textile imports. Such protection was against the spirit and the letter of the GATT, so, in 1956 the protection of the industrial countries was formalized under the Short Term Cotton Textile Arrangement, with the assurance that this was a temporary measure to allow the high-wage countries to adapt. In 1960 the Arrangement was replaced by the Long Term Arrangement, with the assurance that it would not be extended to fibres other than cotton. The low-wage countries had to accept it as a condition for being allowed to take part in the Kennedy Round of negotiations of 1962 to liberalize trade. The Multi-Fibre Agreement was adopted in 1974. Despite the reduction of barriers to trade among themselves, the high-wage countries protected their manufacturing industries against all competing exports of low-wage countries that grew rapidly. These included various types of leather articles, garments and jute products. Yet, through the 1970s and even the 1980s most low-wage countries tried to increase their earnings of foreign exchange by increasing their exports of these kinds of goods, and the prices they received remained low or fell more. 
Since Pakistani exporters were competing against the producers from the high-wage countries, the prices they received were lower than the prices the latter received by the amount of the tariff, at least. They might have been lower still since quantitative restrictions were also used. In other words, the value added at world prices that Pakistan obtained per unit was lowered; for the same investment and labor as the high-wage country firm, the Pakistani firm got less income. Estimates for the years 1954, 1956 and $1959 / 60$ of value added as a ratio of direct and indirect costs of investment using border unit values vary from $7.5 \%$ to $14.8 \%$, depending on the prices of the year. The reciprocals of these ratios are capital:output ratios and they varied between 7 and 14, as compared to what were thought to be appropriate levels for the capital:output ratios for low-wage countries of 2-3. That this was entirely the effect of protection is seen from the ratio obtained by substituting UK factory gate prices for types of cloth exported by Pakistan in the calculation of the value added ratio, which gave $48.3 \%$ and a capital:output ratio of about 2 , numbers that conform more to the idea of a labor intensive activity.

As a rule low-wage countries received the same advice as Pakistan, that cotton textiles, not being capital intensive, conformed to their comparative advantages. There appear to have been no attempts, other than the one mentioned here, to compare actual value added at border prices (i.e., unit values) to the investment involved. Calculation of value added at world prices, as carried out from the mid-1960s to the mid-1980s for several countries, showed that the phenomenon of low value added was a common one and not peculiar to Pakistan, but the people who made the calculations believed that the world markets were efficient and allowed only one price, from which they concluded that the low value added obtained by low-wage countries was in some way the result of their own inefficiency. Given that value added in cotton textiles is essentially the difference between the prices of the raw cotton and of the finished product, inefficiency implied that Pakistani producers used more cotton per unit of yarn or more yarn per unit of cloth than did European or US producers, though none of those who did these calculations of value added went so far as to verify directly whether or not this was true. Such direct evidence as is available supports the contrary belief, namely that the Pakistani producers were reasonably efficient ${ }^{1}$.

The trade barriers against Pakistan's textile exports were typical of the protection that the high-wage countries used against practically all exports of the low-wage countries that competed with their own production.

${ }^{1}$ An extensive survey of discussions of the efficiency of Pakistan's industry can be found in Zaidi, especially in Chapter 8. 
Industrial and agricultural goods, including shoes and various leather products, garments, jute bags, sugar, wheat and beef, were subject to tariffs and quantitative restrictions, and the effect was always to reduce the prices, hence the income, received by the exporting countries. As long as the prices were not lowered to the point that manufacturing firms stopped investing or that wages could not be paid, firms in low-wage countries could be expected to continue to try to export.

No such barriers were needed for goods like coffee, tea, bananas, vanilla, cloves, etc., which did not compete with the production of the highwage countries. But the mutual competition of low-wage country producers kept the prices of these goods low, in the sense that their prices would have been multiples of what they were if the wages of the workers producing these goods had been those of the high-wage country workers. In contrast, goods like cotton textiles would have generated the same income for the low-wage firms as they generated in the high-wage countries if trade had been free and the competition had been between the low-wage and high-wage country firms, though in this case the low-wage would have been offset by high profit rates. All these goods whose prices are determined by low-wage rates not offset by high profit rates will be termed here "low-wage goods".

\section{Complex Goods}

In theory, if the trade barriers of the high-wage countries lower the price of a good so far that it becomes a low-wage good, some of the loss of income can be avoided by not importing the capital equipment needed to make the good but making it in the country instead. By lowering the price of the good the trade barriers lower the rate of profit and, if that is lowered enough, firms in the country can obtain the same rate of profit by making that capital equipment at the price paid for it to the high-wage country firms, the equipment for making that equipment being imported. If the price of the good and the rate of profit from making it are lowered further, the capital equipment is cheaper to make at that rate of profit in the lowwage country than in the high-wage countries. Then, the firms of the lowwage country can start exporting the equipment to the high-wage countries, rather than produce the original good. If the latter countries impose trade barriers against the equipment as well, they lower the price the firms obtain and the locally made equipment becomes cheaper than the imported equipment. Firms in the low-wage country making the original good then obtain higher rates of profit by buying the locally made capital equipment than by buying the same equipment from high-wage country firms. This reasoning can be extended to the capital goods for making capital goods and leads to the conclusion to be expected that, if the trade barriers become 
severe enough, the low-wage country gets its highest rate of return on investment by making all its own capital goods.

Thus, if Pakistani firms had started to produce looms and had been able to export them to the high-wage countries without trade barriers, they would have obtained a higher rate of profit and more income than obtained from exporting cloth, though not as high as what they would have got from exporting cloth if trade had been free. If the high-wage countries put barriers against the import of looms, Pakistani firms making looms would have been able to sell them to firms making cloth at a lower price than imported looms and both sets of firms would have received higher rates of profit than that on importing looms and making cloth. And if the barriers of the high-wage countries were raised to reduce the price of cloth further, the rate of profit from making looms and using them to weave cloth in the country would have been lowered to the point that it became profitable in the same way to make the capital goods for producing looms. In the extreme, if the high-wage country barriers were high enough, Pakistan would have been making all its own capital equipment, which is what is to be expected if the obstacles to trade become too great.

The question that has to be answered, then, is why did Pakistani firms not set up capital goods industries? One answer is obvious: these industries needed scientists and engineers and the country lacked them. Had they not been necessary for such production, firms would have turned to producing capital goods despite the advice of economists about comparative advantages, other things being equal. But the country's higher education did not produce scientists and engineers of the required standards in sufficient numbers. A second answer, one that applies to a particular period, was is that other things were not equal; from 1959 to 1972 the Export Bonus Scheme gave a subsidy to manufactured exports in the form of a more favorable exchange rate than for their inputs. Thus the foreign exchange obtained from exports of cotton and jute manufactures was converted into rupees at roughly 2.5 the exchange rate for the raw cotton or jute.

These subsidies were an important influence on the course of the economy later on, for they came at a crucial period, when the country was supposedly laying the foundations for its future industrial growth by investing in cotton and jute manufacturing. Those products had become low-wage goods but this was hidden by the subsidies. On the one hand, profit margins were raised so high that it was possible to export the manufactures for less foreign exchange than the raw materials used in making them, and, on the other, the dollar value of exports increased so slowly that it only reached the level of 1953, the year of the Korean War 
boom, in 1970. The Export Bonus Scheme also hid the need for improving higher education; the economy seemed to be flourishing without scientists or engineers. Much of the appearance of a flourishing economy was the effect of the large amounts of foreign aid, and when the scheme was ended and foreign aid inflows declined, Pakistan's biggest manufacturing industry by far was cotton textiles, which had to contend with the quotas and tariffs all over the world and competition from other low-wage countries, and which was scarcely able to service the external debt with which it had been built. Not much has changed since then; exports consist of much the same goods and, despite the growth of remittances, the external debt has repeatedly had to be rescheduled.

To discuss why little has changed, goods are divided into two categories, simple and complex. Complex goods are those for whose production higher levels of education and training are needed, engineers and scientists of the level produced by the better universities of the high-wage countries and workers with high levels of training over several years. For present purposes they will all be referred to as trained workers. Making simple goods does not need such trained workers. It does not mean that the workers who make simple goods have no skills. Farmers and weavers require specific knowledge and it may take years to acquire their skill, but they do not receive the education of the trained workers. This distinction is obviously one of degree; there are various levels of training and the engineering or scientific knowledge for building a road is not as complex as that for constructing a long suspension bridge. But it serves to simplify the exposition, which would otherwise become cumbersome without being clearer.

Keeping to free trade for the present, the original process by which low-wage countries displace the production of a good in the high-wage countries has to be modified to allow for the extent the former provide the training needed to make complex goods. As before, the low-wage countries start producing some goods and displace their production in the high-wage countries, which produce more of the goods they import, particularly capital equipment, which is assumed here to consist of complex goods. But, when the demand for simple goods has been met, the low-wage countries can only increase production by making complex goods, as well as nontradable goods. If these countries have the trained workers, the process goes on with the complex goods.

As long as the low-wage country firms produce complex goods that are also made by the high-wage country firms, they obtain, as they did with simple goods, the same prices as the latter and correspondingly higher rates of profit. Their trained workers can be assumed to be paid more than untrained workers, 
though less than workers with the same training in the high-wage countries. Even if the production of a complex good has been completely transferred to the low-wage countries, the rate of profit on its production does not fall below the rate that the low-wage country firms obtain from producing other complex goods that are still made in the high-wage countries. If it did, the firms would reduce their production of that good.

If the numbers of workers being trained in the low-wage countries are too low, simple goods become low-wage goods. Firms that cannot obtain the trained workers they need to make complex goods can only invest in the production of simple goods, and the competition reduces the prices of these goods. Two rates of profit occur in the economies because the lack of trained workers is a constraint preventing the competition between the possibilities of investing in simple or complex goods from evening out the profit rates. Firms that invest in the production of simple goods prefer the lower rate of profit they obtain from that to no profit at all.

Some low-wage countries create more capacity for training workers than do others and, if this capacity is so concentrated in a few countries whose populations are a sufficiently small part of the total, these countries reach full employment producing complex goods whilst the production of simple goods is left to the others. For, as the production of complex goods in the low-wage countries displaces the production of the high-wage countries, these countries increase their production of these goods and, because of their relatively small population, may reach full employment while the others have unemployment. In these countries the wages of untrained workers rise and the wages of trained workers rise with them, unless there is such an excess of trained workers as to lower the margins by which their pay exceeds that of untrained workers. Other low-wage countries may also produce complex goods, to the extent that they have trained workers and the pay of their trained workers may be as high, since there is a shortage of them and the rate of profit from producing complex goods in these countries is higher because the untrained workers are paid the same low-wage as before. A low-wage country that has an especially big population may have a large production of complex goods and yet much of the population may be seeking work in its industries.

From this it follows that Pakistan and other countries exporting cotton textiles did not start producing their own capital equipment (machinery for spinning and weaving) because it consisted of complex goods and these countries did not have the trained workers needed to make them. Had the authorities and private firms invested in scientific and engineering education at university level at standards comparable to those of Europe and the US and had they provided correspondingly high standards of training for 
workers below university level, the manufacture of such capital goods could have started, even though trade was not free. But the authorities did not regard education in this way. At first, until the 1970s, they regarded education as a social expenditure that would have to wait until an industrial "breakthrough" had been made and then, following the advice they received, higher education in sciences and engineering was considered not to conform to the country's comparative advantages, which does not mean that much has been done for primary and secondary schooling either. Private investment in higher education was also late in coming; it did not seem profitable at first and upper-income families could send their children abroad for studies. Even now, though the demand for education makes investment in it profitable at all levels, only a small proportion of higher education in sciences and engineering can compare with the standards of the high-wage countries.

\section{R\&D and Proprietary Knowledge}

This explains why Pakistan now manufactures little that it did not manufacture in the 1960s. But it does not explain why almost all brand names that are known beyond their own countries belong to high-wage country firms. Until recently the main exception was Korea, though Taiwan and Singapore were equally advanced economically and also had some brand names. It is only recently that brands from low-wage countries, notably China $^{2}$ and India, have begun to be known outside their home countries.

One way of explaining this phenomenon is through technical progress. For the purposes of the present discussion, technical progress will be divided into three sorts. One is the autonomous technical progress that is often assumed in economic models, whereby output, given the labor, capital and any other factors that might be invoked, simply increases with time. Apart from being assumed to be costless and exogenously given, it can be given whatever mathematical properties are thought convenient. The second is the progress gained from experience, for example, Arrow's "learning by doing", though it goes back to Adam Smith's pin maker, who gained dexterity by practising a single operation. Empirical work has proved its practical importance, particularly in the making of complicated goods, such as aircraft, and show that the man-hours needed to produce a unit decline with the number of units already produced, the so-called "learning curve". One reason that it has been used less often in economic models is that the relation of productivity to previous output makes the mathematics intractable.

\footnotetext{
${ }^{2}$ For present purposes, the country China is taken as comprising three separate economic systems, referred to here, for the sake of brevity, as China, Hong Kong, and Taiwan.
} 
Both these forms of technical progress have the additional deficiencies that they treat the final goods as given, whereas much of the competition of international trade consists of producing new goods and improved versions of existing goods. Manufactured goods almost always have several, perhaps many, versions or models. For instance, all makers of motor cars have several models at a time and each model has a number of variations, such as color, type of seats, manual or automatic gears, etc. Two motor cars may differ in hundreds of particulars, but they are, nevertheless, both motor cars and the same good. With such goods, which can be referred to as "differentiated", different firms make different versions because, unless there is agreement to make the same version, patent and copyright rules oblige them to do so. Apart from manufactures, most agricultural products are differentiated goods. Wheat, bananas, apples, beef, coffee and so on come in different varieties and, through breeding and, nowadays, genetic engineering, the varieties on offer change. Often there is no restriction on producing a particular variety of a crop, but sometimes varieties are also protected by patents and copyrights.

Neither autonomous technical progress nor learning by doing allows for their costs. So much of technical progress is the outcome of research and development (R\&D) by firms and specialized public sector agencies that the first two can be ignored here. $\mathrm{R} \& \mathrm{D}$ is deliberate expenditure to obtain specific knowledge that allows the production of an improved good. It has costs, but, for the private firm the knowledge it generates can give an advantage over competitors, who can be prevented from using that knowledge by patent laws and firm secrecy. That knowledge belongs to whichever firm or agency generated it and is "proprietary". It remains proprietary as long as the patents are in force and secrecy can be kept. Competitors cannot use it, unless they can get the right to do so, for which they usually have to pay. It is assumed here that patents expire after a fixed time and that all knowledge that is not protected by patents is generally available, i.e., secrecy can be ignored. Goods are, therefore, of three kinds, simple goods, complex goods and goods that require proprietary knowledge to make, whether it be because of the design of the good, itself, or the process by which it is made.

It is also assumed that producers are in competition, which implies that every good of the third kind can be made in several versions. When $R \& D$ results in a version of a good that displaces an existing version in the same country, what can be described as an 'improved' version, the displaced version cannot be made and sold in the country to give a rate of return as high as can be obtained in other activities and, if competition persists, it is because different producers offer competing versions, without infringing on 
each other's proprietary rights, by devising different ways of giving their goods their characteristics. It is assumed here that they obtain roughly the same rates of return on their investment, including the R\&D. Hence, when one firm produces a version of a good because of its R\&D there are other firms producing the good that, through their $\mathrm{R} \& \mathrm{D}$, produce versions that compete in this way. Even a firm that has not produced the good before can, by doing its own R\&D, acquire the knowledge needed to produce versions of the good that would have been up to date at the time it began its efforts, i.e., could have competed with those being sold then to yield the same wage and profit as they did. The firm would not necessarily be able to compete while paying the same wages, for this acquisition of knowledge takes several years, during which the established producers can continue to spend on R\&D and add to their knowledge. Unless it obtains the up to date proprietary knowledge of the more advanced firms, the firm remains backward compared to them.

Low-wage country firms cannot be expected to compete with highwage country firms by doing $\mathrm{R} \& \mathrm{D}$ comparable to theirs. They cannot catch up; while they do whatever R\&D they can, the high-wage country firms move on, probably spending more, even allowing for the lower pay of the low-wage countries. High-wage country firms also recruit many of the best scientists and engineers of the low-wage countries, often with the help of their authorities.

But is it necessary for the low-wage countries to be at a technical level comparable to that of high-wage country firms? Fifty years ago the living standards of the mass of the population of the US and Northwest Europe were higher than are those of the bulk of the populations of Pakistan, India and most countries of Africa and Latin America now. Direct comparisons are not possible because of the differences of goods, but if the bottom $80 \%$ of the population of Pakistan had the choice, they would prefer being in their present percentiles in, say, Germany, France, the UK, Holland or the Nordic countries of fifty years ago to what they have now. If this is accepted, it means that the techniques of production then were good enough to allow higher living standards in low-wage countries now. It is not the lack of access to recent scientific and technical knowledge that prevents incomes from being higher. In principle, Pakistan and similar countries could have higher living standards for most of their populations using the knowledge of 50 years ago. And, since patents do not last 50 years and much recent knowledge is not proprietary, using generally available knowledge should allow living standards that are higher than were those of these countries then. So what prevents these countries from installing industries using generally available knowledge? 
The answer to this question is that recent versions of goods are usually so much preferred to older version that the older version cannot be even be made and sold profitably by firms in low-wage countries. To illustrate, motor cars made with the technical knowledge of 1970 would now find no buyers willing to pay their production costs. They would lack the reliability, power, fuel efficiency, stability and comfort that are expected of vehicles now. Much the same is true of television sets, cameras, airplanes and many medical devices. Occasionally a low-wage country firm has been able to sell a technically backward version of a good in competition with technically advanced versions of high-wage country firms of the same good because it was cheaper, but such cases are rare. Moreover, markets for such cheap, technically backward versions of goods are often uncertain, for the next technically advanced version could result in the price of the cheap version falling further.

Hence, firms in a low-wage country only using generally available knowledge to produce goods cannot compete with advanced versions of the same goods made with the proprietary knowledge of the high-wage country firms, unless the domestic market is sufficiently protected against competition from imports. They cannot sell them abroad and domestic buyers will only buy them if the alternatives are unavailable or too expensive. An economy relying entirely on generally available knowledge can provide a higher living standard for the population not belonging to the upper income groups, but it would have to be protected. To the extent that it needs to import primary products that the country cannot produce itself and does not have natural resources to export that yield an economic rent, such as minerals, it would have to subsidize exports. The reason is that its exports of manufactures would be the same as those of other low-wage countries, but its wages and costs of production would be higher.

There is no paradox here; the conclusion is the consequence of the constant improvement of goods by $\mathrm{R} \& \mathrm{D}$ and the proprietary nature of the relevant knowledge. The orthodox propositions about the efficiency of free trade and the higher incomes that result are derived from the Ricardian and neo-classical theories of trade, neither of which has differentiated goods and in which competition is confined to price alone. In these theories any firms that can produce a good can produce only the same good and all that tariffs do is alter the relative prices of different goods and, hence, the prices of the factors producing them. How little this is relevant to the trade in manufactures can be seen from the competition in motor cars, telephones or refrigerators, where different producers offer models with different features, which matter as much as price. This is much the same reasoning as that of the infant industry argument of Alexander Hamilton and Friedrich List. They, too, argued that the 
superior products of the most advanced industries of their time, those of Britain, would be preferred to those of the less advanced industries of the American and German states. It refers to final goods, in contrast to the infant industry argument as put forward under the influence of the Ricardian and neoclassical theories, that protection is needed to lower costs.

Where the infant industry argument of Hamilton and List is unsuited to modern low-wage countries is the assumption that protection allows the firms of these countries to catch up and produce equally advanced goods. As already pointed out, the firms of high-wage countries spend on R\&D to design new versions of goods, invent new goods and improve their production processes because their ability to compete depends on it. A low-wage country firm starting to produce a good cannot expect to be able to compete with the versions of high-wage country firms that have been doing R\&D for a long time and through which they have accumulated proprietary knowledge that will be protected by patents for several years. There have been exceptions, for instance one of the Korean motor car makers became competitive in international trade through its own R\&D, but they are rare and, in this case, the firm benefited from a protected domestic market at the early stages. Normally a low-wage country firm would need several years to reach the point at which the high-wage country firms are already, during which time these firms would have continued with their own R\&D, and it would not have comparable R\&D facilities, trained workers and financing.

An alternative for a low-wage country firm to catching up through its own R\&D is to buy proprietary knowledge. This, too, does not happen often. When firms need their R\&D and the proprietary knowledge it generates to be able to compete, they are normally oligopolies. There are several reasons for that, including the necessity for firms to differentiate their goods from those of their competitors and the likelihood that the numbers of solutions to technical problems and the numbers of patents that can be issued for them may be small. Without going into a detailed explanation, it seems that oligopolies are the rule. Even when firms are not big, they are specialized and oligopolies in their own branches.

This means that a firm that needs its advanced proprietary knowledge to compete will be reluctant to provide it to another firm that intends to become a new competitor, especially as the versions of the good the new competitor would produce would be close to its own. Then there may be no price that would compensate the firm selling its proprietary knowledge for the additional competition and also allow the newcomer to be profitable. At best the proprietary knowledge sold might be out of date 
or incomplete, which would yield additional income for the firm selling it, whilst the buying firm might not have the expertise to tell until too late.

Foreign direct investment by high-wage country firms can result in some production involving proprietary knowledge in low-wage countries. For instance, some German motor car manufacture has been transferred to Eastern Europe. But high-wage country firms that have invested in generating proprietary knowledge do not often transfer their most advanced proprietary knowledge to subsidiaries in low-wage countries. One reason is that few such countries have the scientists and engineers with the appropriate levels of training. This may not be a problem for activities that do not need such highly trained workers because they can be automated with just a few expatriates to supervise, but, since the reason for the investment is the lower cost of labor, there is little point in it. In some countries which do have highly trained workers, local firms and the authorities have industrial ambitions and there is the risk that they try to obtain the proprietary knowledge by inducing workers to join them or even through espionage. Consequently, when foreign subsidiaries are used for production requiring advanced proprietary knowledge, they usually do not produce the entire good, but are limited to components or some steps in the production of components. Similarly, because their ability to compete depends on their proprietary knowledge, high-wage country firms have, up to now, kept their R\&D capacities in the high-wage countries, although they could, in principle, reduce the costs by transferring it a low-wage country that has the requisite scientists and engineers. This may change in time, but at present it is rare.

Assuming that it is unrealistic for a low-wage country's firms to compete with those of high-wage countries in the production of goods for which proprietary knowledge is needed, what are the alternatives when trade is free? One is to produce complex goods for which generally available knowledge is adequate. Much of the globalization that has occurred over the last thirty to forty years has consisted of the transfer of such production to low-wage countries, through foreign direct investment by high-wage country firms and through low-wage country firms producing for firms or the markets of the high-wage countries. This kind of globalization has been sufficiently concentrated in a few countries that the incomes of trained workers have risen to levels much above the pay of untrained workers. Unemployment in these countries has been reduced, but not enough for the wages of untrained workers to have risen much, and the conditions of work have not improved noticeably, despite the efforts of socially conscious and humanitarian movements in the low and high-wage countries. 
Whether or not the continued transfer of the production of complex goods of this kind will eventually lead to full employment in some of these countries depends on how great a part these goods constitute of the world's total absorption of goods. If they are only a small part, all their production will have been transferred to the low-wage countries without ending unemployment there. If they are a sufficiently large part, at least some lowwage countries may reach full employment. But, since China and India account for almost half the world's population, the likelihood of full employment being reached in this way is small.

\section{Subcontracting for High-Wage Country Firms}

Another alternative is subcontracting. Much of the production for export of China, Korea and Taiwan consists of components or stages in the production of components of final goods for firms of high-wage countries, though other parts of the production process may take place in other countries. These are economies that train enough scientists and engineers to high enough levels for firms of high-wage countries to transfer to them the proprietary knowledge needed for such activities and to provide training. Subcontracting of this sort is a form of collaboration between two firms, a low-wage country firm with trained workers trying to start forms of production that yield more profit and a high-wage country firm with proprietary knowledge that wants to lower some of its labor costs. Yet the latter try not to transfer so much of their knowledge as to create new competitors. ${ }^{3}$

Normally, collaboration allows both firms to obtain higher profits than they would otherwise and makes both, therefore, to want it to last. There is a range for the prices for the components that the low-wage country firm produces; they cannot be below what yields profit rates no higher than the firm would obtain otherwise and cannot be so high that they do not reduce the costs of the high-wage country firm. Both firms, therefore, benefit from collaboration by agreeing to prices between these extremes. Neither benefits from pricing at the extremes. By providing some of its proprietary knowledge and training the high-wage country firm makes an investment intended to reduce its costs over several periods and it can expect that, later, providing new knowledge generated by its $R \& D$ and the associated training to the firm with which it is already collaborating will, unless that firm has some specific drawback, cost less than would starting collaboration with another firm. The firm receiving the knowledge knows that it must keep acquiring the new knowledge for the collaboration to continue and keep it from others. This is

\footnotetext{
${ }^{3}$ This has often been commented on. Specific examples are given by Cyhn, among others.
} 
not pricing as in perfect competition for competition cannot be perfect when knowledge is proprietary.

Over time the collaboration can expand to the low-wage country firm taking on more components and even doing some of the related R\&D. Then the firm can grow and increase its profits whilst its trained workers increase their technical knowledge and, perhaps, get paid more. As long as the knowledge does not allow the firm to compete with the high-wage country firm, the collaboration is stable. This can also be ensured by the latter firm taking control or acquiring part of the ownership of the former, which allows the collaboration to go further still.

From this stage a low-wage country firm can try to start producing final goods, for which it must fill the gaps in its R\&D capabilities and knowledge. It has the additional obstacle that it must establish its brand name, for goods that are differentiated or made with proprietary knowledge nearly always have to have brand names to be marketable. When buying dishwashers, forklift trucks or batteries, buyers want to have some assurance of quality and, where necessary, guarantees and services for maintenance and repair. Households rarely buy batteries that are not standardized, but they use the brand names to guide them on the quality and price. For dishwashers or air-conditioners they want to be assured that the appliances will be replaced if defective and that they can rely on repair services. Much the same is true for capital goods not made to order, like forklift trucks and power looms; firms that buy them want to avoid having to check everything in advance and reduce the need to do so by relying on brand names.

But establishing a brand name is so costly and uncertain that many firms prefer to remain subcontractors, though they may diversify by collaborating with several different firms and broadening the range of activities. When a low-wage country firm does want to establish its brand, it begins in its own country and tries to acquire a share of the market from the established firms. Under free trade even this may be difficult, since the established brands are likely to belong to high-wage country firms, who have the advantages of greater R\&D capabilities and the ability to supply new versions more often. Such Korean and Taiwanese firms as have established their brands in the high-wage countries since the 1970s have been conglomerates able to incur the costs and take the risk. But, in the early stages of establishing their brand names in their own countries, even they benefited from protection and they had inducements from the authorities to export, which, for the conglomerates, meant establishing brand names abroad. 
When China began to allow private enterprise and to acquire proprietary knowledge from high-wage country firms it, too, had the scientists and engineers needed for subcontracting. But, in relation to the size of the population and the paucity of private firms, entering into individual collaborative arrangements with foreign firms would have been too slow. In contrast to Korea and Taiwan, which, like Japan earlier, had restricted direct investment by foreigners in order to prevent them from controlling firms in their economies, China allowed it on a large scale. But the authorities kept control and their permission was required. For foreign firms China could be a big market because of the size of the population, but, because it was a market protected by tariffs and import controls, they often had an inducement to invest and manufacture in it, rather than to export to it. That enabled the Chinese authorities to impose conditions, in particular to make them enter into partnerships with Chinese firms and to transfer proprietary knowledge to them. Because of adroit use of the controls, for which their ministries developed units with expert staff, nearly all the investment by foreign firms seems to have gone in to partnership with Chinese firms for the production of components and goods requiring proprietary knowledge. Consequently, in addition to the big population, China had rapidly growing exports, comprising both low-wage and technically advanced goods, and rising incomes, all of which have increased the motivation for foreign firms to invest in the economy and, if necessary, to impart their knowledge. The combination of fast economic growth and the restrictions on the freedom of foreign firms to expand alone in the domestic market have allowed Chinese firms to expand and establish their brand names both at home and abroad, whereas Chinese brand names were virtually unknown in the high-wage countries only a few years ago.

India has some of the same elements as China, including the ability to train scientists and engineers, controls over foreign investment and protection of the domestic market. But it has not provided inducements to its firms to have subcontracting arrangements with high-wage country firms, as did Korea and Taiwan, and has not shown the same persistence in using the attraction of the market offered by its large population to oblige foreign firms to make partnerships with domestic firms and to transfer their knowledge to them. Consequently, India has not acquired the proprietary knowledge of high-wage country firms to the extent China has. Thus, the purchase by an Indian firm of two British car makers close to bankruptcy may have been a means of acquiring their proprietary knowledge for use in making cars in India, possibly for export later on. But Indian firms have used generally available knowledge, as well as knowledge they could obtain though it was still proprietary, to provide cheap alternatives to the goods of high-wage country firms. One example has been the manufacture of 
pharmaceuticals, where products developed by high-wage country firms are being made by Indian firms and sold cheaply, often as generics. Sometimes the knowledge became generally available or was acquired through chemical analysis by the Indian firm while the patents were in force, but it was mostly gained independently of the firms whose R\&D had generated it. Software development seems to be an unusual case of a low-wage country's firms undertaking $\mathrm{R} \& \mathrm{D}$ for high-wage country firms. Indian firms may not be the most advanced in this kind of $R \& D$, but what they provide is advanced enough for many users and may be the precursor of R\&D for foreign firms in other branches.

\section{Comparative Advantages}

Since it takes wages as given, the discussion here is the reverse of the notion of comparative advantages. Whether they are as conceived by Ricardo, with costs proportional to the labor required, or they are given by relative endowments of factors, as with the Hecksher-Ohlin or factor endowments theory, comparative advantages determine wage rates. In the discussion above the patterns of production and trade at any time are the cumulative results of investment in earlier periods and of changes in prices and wage rates.

In contrast, comparative advantages are static; in particular, they are confined to single-period models, which makes them unsuitable for discussing economic development. Given the comparative advantages at any time, i.e., the amounts of labor needed per unit of output or the endowment of factors, equilibrium for that time is determined. Wages are determined independently of what went before or comes afterwards. Profits do not arise in Ricardian comparative advantages, but in the factor endowments theory they are a factor price and are, in the same way, determined only by the patterns of endowments and preferences of the present. How the productivity of labor or the endowments of factors came to be what they are, presumably the questions that matter, have to be explained separately.

Being single-period models, they are inconsistent with the existence of capital goods, i.e., produced means of production, which presuppose at least one period for their production and at least another for their use. Ricardian theory, since it assumes that costs are proportional to the labor used, does not have capital goods. Even if it could be modified to be an inter-temporal model with capital goods, the proportionality of cost to 1abor needed would require too much of a restriction to be justified. The factor endowments theory, too, is inconsistent with the existence of capital goods. 
A country's endowment of capital is a stock of capital goods, the result of investment in these capital goods that was partly determined by their prices, which in turn depended on which countries they were produced in. Some of the capital goods may have been produced in one country and others in another. Hence, if factor endowments determine the patterns of production and trade, they are also determined by the patterns of production and trade. There is a circularity arising from the characteristic of capital goods, that they both yield profits and have costs of production. In equilibrium the two must be equal (using the appropriate discount or interest rates). The singleperiod factor endowments model, by taking the quantity of capital as given and equating the profit rate to the marginal product, ignores the costs of production, unless it assumes capital goods away, e.g., by supposing the factors to be land and labor.

This reasoning is a variant of Sraffa's criticism of the concept of capital as a quantity of goods: the value of the stock of capital goods of a country depends on the wage and profit rates in its production and cannot in general, therefore, be taken as determining these rates through the marginal products of labor and capital. If Sraffa's criticism holds for the closed economy, in which wage and profit rates are assumed to be uniform, it holds all the more with international trade between countries whose wage and profit rates differ.

Despite the objection, models of international trade using capital as an aggregate quantity, instead of as heterogeneous, durable goods, are common and some of them even include trade in this kind of capital. They suppose capital to be literally a homogeneous, malleable substance, or possibly several such substances, otherwise the objection outlined here holds. Consequently, they have the drawback of obscuring the questions that are of most interest to low-wage countries, namely should they produce capital goods, if so which ones and how does this affect the criteria for making investment decisions? If high-wage countries have trade barriers, the criteria might have to take that into account, for barriers can alter the prices of exports relative to the prices of the capital goods for making them and create a difference between the import and export prices of goods, or the prices exporters receive and those paid by users. 


\section{References}

Arrow, K.J. (1962). The Economic Implications of Learning by Doing. Review of Economic Studies, $24: 155-173$.

Cyhn, J.W. (2002). Technology Transfer and International Production: The Development of the Electronics Industry in Korea. Princeton University Press: Edward Elgar.

Sraffa, P. (1960). The Production of Commodities by Means of Commodities, Cambridge University Press: London.

Zaidi, S.A. (1999). Issues in Pakistan's Economy. Oxford University Press: Karachi. 